\title{
Editorial
}

\section{World Food Summits: what for, and what value?}

Last November, Jacques Diouf, Director-General of the FAO, called together a World Summit on Food Security in Rome. Seven of the leaders of the G8 countries (the USA, Russia, Japan, Germany, France, the UK, Canada and Italy) failed to attend (only Italy's prime minister was present) ${ }^{(1)}$. Nevertheless, we would like to see a favourable development from the 2009 meeting, held at a time in history when hunger problems have escalated immensely. What were the events that led to this last summit, and what was (or is) its importance?

\section{Other summits}

The 2009 World Food Summit was preceded by two others, held in 1996 and 2002. The Rome Declaration from the first Summit stated: 'We, the Heads of State and Government, or our representatives, gathered at the World Food Summit at the invitation of the Food and Agriculture Organization of the United Nations, reaffirm the right of everyone to have access to safe and nutritious food, consistent with the right to adequate food and the fundamental right of everyone to be free from hunger. We pledge our political will and our common and national commitment to achieving food security for all and to an ongoing effort to eradicate hunger in all countries, with an immediate view to reducing the number of undernourished people to half their present level no later than $2015^{,(2)}$.

The weak improvement in the global hunger situation motivated the organisation of the 2002 Summit, which consolidated the concept of the human right to food. This was a direct follow-up of the 1996 Summit, and called for a development of the so-called Right to Food Guidelines by UN member countries. In 2009 FAO issued a Right to Food Toolbox ${ }^{(3)}$, to support the implementation of its rights-based approach to food security and to address nutrition within a human right to food approach.

In 2008 the global economic crisis struck, leading to a world food price crisis and a dramatic rise in food insecurity $^{(4,5)}$, and providing the immediate call for a third summit.

\section{The 2009 Summit}

Dr Diouf welcomed attendees of the 2009 Summit with these words: 'One billion hungry people [...] This is our tragic achievement in these modern days when our technology allows us to travel to the moon and to space stations $^{(6)}$. He went on to emphasise the need to produce food and boost agricultural development in the areas where poor and hungry communities live ${ }^{(6)}$. Amplifying this point, European Union (EU) President José Manuel Barroso declared, 'A world where one billion people are hungry is not just a deep stain on our collective conscience: it is a growing threat to our collective global security $^{\text {(7) }}$. He stressed the importance of a system that gives early warning of food security crises, and highlighted the work of the EU's Food Facility for channelling $€ 1$ billion into food production in low-income countries, of which $85 \%$ will be allocated before the end of 2009 .

Among the outcomes of the 2009 World Summit ${ }^{(8)}$ were a declaration 'to undertake all necessary actions required [...] to halt immediately the increase in - and to significantly reduce - the number of people suffering from hunger, malnutrition and food insecurity'; and the following Five Rome Principles for Sustainable Global Food Security:

1. Invest in country-owned plans, aimed at channelling resources to well-designed and results-based programmes and partnerships.

2. Foster strategic coordination at national, regional and global levels to improve governance, promote better allocation of resources, avoid duplication of efforts and identify response gaps.

3. Strive for a comprehensive twin-track approach to food security that consists of (i) direct action to immediately tackle hunger for the most vulnerable and (ii) medium- and long-term sustainable agricultural, food security, nutrition and rural development programmes to eliminate the root causes of hunger and poverty, including through the progressive realisation of the right to adequate food.

4. Ensure a strong role for the multilateral system by sustained improvements in efficiency, responsiveness, coordination and effectiveness of multilateral institutions.

5. Ensure sustained and substantial commitment by all partners to investment in agriculture and food security and nutrition, with provision of necessary resources in a timely and reliable fashion, aimed at multi-year plans and programmes.

Disappointed reactions to the Summit were immediate. In negotiations over the Summit's draft declaration, wealthier nations succeeded in removing a goal to end world hunger by 2025 , replacing it instead with a goal to eradicate hunger 'at the earliest possible date ${ }^{\text {(1) }}$. Further, whereas the FAO had hoped for an agriculture aid target of \$US 44 billion annually towards helping farmers in 
poorer countries, the draft declaration instead committed merely to 'substantially increase' agriculture aid. President Barroso's pledge that $20 \%$ of G8 money would come from the European Commission 'was a repacking of existing commitments' and not the commitment of any new funds, pointed out Francisco Sarmento, Head of Food Rights at ActionAid ${ }^{(9)}$. Mr Sarmento also remarked that the role of sustainable agricultural production was not addressed: "World leaders have overlooked the opportunity to follow more sustainable options helping to mitigate climate change and feed the world ${ }^{(9)}$.

'We end up leaving with a stomach full of promises and think we have found a solution', said Amadou Toumani Touré, President of Mali. 'Then, at the next conference, we start all over again, (10).

\section{Where does the 2009 Summit leave us?}

In the words of ActionAid's Regional Director for Latin America, 'Warm words do not fill empty stomachs, ${ }^{(9)}$. So far, international food and nutrition policies have lacked implementation and evaluation plans, budget allocation, and clear divisions of responsibility.

But positive dimensions of the declaration deserve attention. The 2009 Principles ${ }^{(8)}$, building from previous documents, do use the word 'nutrition' several times, whereas it was not mentioned before. Additionally, the third principle includes a reference to the human right to adequate food, despite active resistance to the concept by many countries; reference to it here is a victory for a human rights approach, and makes clear that accountability and transparency are important values in the struggle against malnutrition and hunger.

Let us hope that the words from the 2009 Summit do in fact reflect a change in attitude among many policy makers, and a belief that it is simply wrong that people die of hunger and malnutrition. Let us keep track of whether the words from this Summit lead to action. And let us continue to urge our policy makers not to doom these Summits to failure, or the people they represent to hunger.

\section{References}

1. MacFarquhar N (2009) Disagreement over goals at UN meeting on hunger. New York Times, 16 November; available at http://www.nytimes.com/2009/11/17/world/ 17food.html?_r=1

2. Food and Agriculture Organization of the United Nations (1996) Rome Declaration on World Food Security. Rome: FAO; available at http://www.fao.org/docrep/003/w3613e/ w3613e00.HTM

3. Food and Agriculture Organization of the United Nations (2009) Right to Food Methodological Toolbox. http:// www.fao.org/righttofood/ (accessed December 2009).

4. Yngve A, Margetts B, Hughes R et al. (2009) Editorial on the occasion of the International Congress of Nutrition. World hunger: a good fight or a losing cause? Public Health Nutr 12, 1685-1686.

5. Yngve A, Margetts B, Hughes $\mathrm{R}$ et al. (2009) Food insecurity - not just about rural communities in Africa and Asia. Public Health Nutr 12, 1971-1972.

6. Food and Agriculture Organization of the United Nations (2009) World Summit on Food Security, Rome, 16-18 November 2009. Opening Statement of FAO DirectorGeneral, Dr. Jacques Diouf. http://www.fao.org/wsfs/wsfslist-documents/en/ (accessed December 2009).

7. European Union @ United Nations (2009) Summary: 16 November 2009, Rome - Statement by José Manuel Durão Barroso, President of the European Commission, at the FAO High Level Summit on Food Security. http:// www.europa-eu-un.org/articles/en/article_9229_en.htm (accessed December 2009).

8. Food and Agriculture Organization of the United Nations (2009) World Summit on Food Security, Rome, 16-18 November 2009. Declaration on the World Summit on Food Security. http://www.fao.org/wsfs/wsfs-list-documents/en/ (accessed December 2009).

9. ActionAid (2009) World Food Summit throws away chance to stop one billion going hungry. http://www.actionaid. org/main.aspx?PageID =1390 (accessed December 2009).

10. Maier K \& Donovan J (2009) Food Summit opens with censure of greed, speculation (Update2). Bloomberg.com, 16 November. http://www.bloomberg.com/apps/news? pid $=20601085 \&$ sid $=$ aIu8hiyAkZCw $\quad$ (accessed December 2009). 